\title{
NOTY PROWENIENCYJNE I WŁAŚCICIELE KSIĄG BIBLIOTEKI KLASZTORU CYSTEREK W TRZEBNICY W ŚWIETLE INWENTARZA HELENY SZWEJKOWSKIEJ ${ }^{1}$
}

\begin{abstract}
Noty proweniencyjne wyszczególnione w inwentarzu Heleny Szwejkowskiej w doskonały sposób odzwierciedlają losy ksiąg należących do jedynych śląskich cysterek w Trzebnicy² opactwa ufundowanego przez Henryka Brodatego w I2O2 roku, który za namową św. Jadwigi „własnym kosztem zbudował klasztor w Trzebnicy dla mniszek zakonu cysterskiego”. Znakomita większość z ksiąg została opatrzona w przeszłości co najmniej jednym wpisem
\end{abstract}

* Katarzyna Zielonka, absolwentka historii na Wydziale Nauk Historycznych i Społecznych Uniwersytetu Kardynała Stefana Wyszyńskiego w Warszawie. Zainteresowania naukowe: historia książki i bibliotek ze szczególnym uwzględnieniem księgozbiorów klasztornych w średniowieczu i epoce nowożytnej. E-mail: katarzynascieginska@ wp.pl.

1 Artykuł stanowi uzupełniony fragment pracy magisterskiej pt. Księgozbiór historyczny panien cysterek $w$ Trzebnicy od XV do XVIII wieku w świetle inwentarza Heleny Szwejkowskiej, obronionej w 2016 roku na Wydziale Nauk Historycznych i Społecznych Uniwersytetu Kardynała Stefana Wyszyńskiego w Warszawie.

2 Pierwsze panny siostry przybyły do Trzebnicy z Bambergu, a godność pierwszej ksieni objęła benedyktynka Petrusa, dawna nauczycielka księżnej z opactwa Kitzingen. Nie bez znaczenia w procesie fundacji były koligacje rodzinne św. Jadwigi, która prawdopodobnie korespondowała ze swoją rodziną w tej sprawie. W tamtejszym klasztorze św. Teodora i NMP profeską była siostra Jadwigi - Mechtylda, tamtejszym biskupem był jej brat Ekbert, a prepozytem kapituły bamberskiej - stryj Poppon. W latach 1232-1268 godność ksieni trzebnickiej piastowała córka fundatorskiej pary, Gertruda. Po śmierci księżnej Jadwigi w 1243 roku, owa ksieni podjęła starania o kanonizację swej matki, która odbyła się w 1267 roku, za pontyfikatu papieża Klemensa IV. Dzięki temu Trzebnica stała się w krótkim czasie ważnym centrum pielgrzymkowym, ściągającym wiernych do grobu świętej. Klasztor w kolejnych wiekach stanowił istotny ośrodek przyciągający kandydatki do życia zakonnego, także wywodzące się z rodów książęcych. Od połowy XIV do połowy XV wieku przebywało w nim sześć Piastówien górnośląskich. W XVI stuleciu w klasztorze szerzyły się nowinki religijne związane z podziałem mniszek na dwie konkurujące ze sobą frakcje narodowościowe: Niemki i Polki, zwalczające się w późniejszych latach z mniejszym lub większym powodzeniem. Zob. M. Kanior, Pierwsze fundacje cysterek na ziemiach polskich, w: Cysterki w dziejach i kulturze ziem polskich, dawnej Rzeczypospolitej i Europy Środkowej, red. A. M. Wyrwa, A. Kiełbasa, J. Swastek, Poznań 2004, s. 40; J. Swastek, Rodzina świętej Jadwigi, w: Księga Jadwiżańska. Międzynarodowe Sympozjum Naukowe „Święta Jadwiga $w$ dziejach i kulturze Ślaska”. Wrocław-Trzebnica 21- 23 września 1993 roku, red. M. Kaczmarek, M. L. Wójcik, Wrocław 1995, s. 48-49; A. Doroszewska, Otoczenie Henryka Brodatego i Jadwigi jako środowisko spoleczne, Warszawa 1978, s. 14; M. Kaczmarek, ...Ut et matris et matertere memoriam confoveret. Klasztor trzebnicki pod rzadami opatki Gertrudy (1232-1268), w: Cysterki w dziejach i kulturze ziem polskich, dawnej Rzeczypospolitej i Europy Środkowej, red. A. M. Wyrwa, A. Kiełbasa, J. Swastek, Poznań 2004, s. 331; W. Bochnak, Niewiasta mężna i czcigodna. Z życia i działalności św. Jadwigi Śląskiej, w: Bulla kanonizacyjna św. Jadwigi Ślaskiej, red. W. Bochnak, Legnica 2014, s. 32; M. Warzecha, Księżniczki z domu Piastów górnośląskich w klasztorze trzebnickim, w: Cysterki w dziejach i kulturze ziem polskich, dawnej Rzeczypospolitej i Europy Środkowej, red. A. M. Wyrwa, A. Kiełbasa, J. Swastek, Poznań 2004, s. 489-496.; A. Sutowicz, Polska książka w ręku cysterek trzebnickich. Przyklad XVII-wiecznych modlitewników przechowywanych w Bibliotece Uniwersyteckiej we Wrocławiu, ,Świdnickie Studia Teologiczne”, 10/2013, nr 10, s. 354.

3 Zob. Legenda świętej Jadwigi, tłum. A. Jochelson, M. W. Gogolewska, Wrocław 1993, s. 58. 
własnościowym. Ich mnogość sprawia, że stanowią one ciekawe źródło do poznania dziejów poszczególnych pozycji ${ }^{4}$. Istotną kwestią do ustalenia pozostają drogi, którymi pozyskiwano księgi dla klasztoru. Jedną z najczęstszych było kupno oraz różnego rodzaju darowizny. Księgozbiór powiększał się także na skutek gromadzenia pozycji niezbędnych dla ojców duchownych, którzy, pełniąc posługę wśród mniszek trzebnickich, sami niejednokrotnie przywozili potrzebne księgi. Najliczniejszą ich grupę stanowiła prywatna własność panien sióstr, która weszła w zasób biblioteki5. Warto przy tym zaznaczyć, że Statuty Edmunda od Krzyża z I580 roku zakazywały cysterkom przyjmowania darów i wyznaczały czas na czytanie w wolnych chwilach od modlitwy jedynie takich dzieł „któreby ie do pobożności pobudzały: y które spowiednik będzie widział, y aprobował" ". W niniejszej pracy omówione zostaną te noty proweniencyjne, które można zebrać w osobne kategorie, co pozwoli przedstawić ich charakter oraz drogę, jaką poszczególne pozycje przebyły zanim weszły w skład księgozbioru trzebnickiego, a także w miarę możliwości późniejsze zmiany ich właścicieli.

W oparciu o wspomniane wpisy jako pierwsze zostaną przedstawione te księgi, które dostały się do Trzebnicy za sprawą ojców duchownych pełniących posługę wśród mniszek. Trzy z nich stanowiły dary późniejszego opata klasztoru cystersów w Jemielnicy ${ }^{7}$ Eugeniusza Lengi ${ }^{8}$. Jego obecność w Trzebnicy była możliwa ze względu na uzyskanie przez cysterki zezwolenia od generała zakonu Edmunda od Krzyża, nadającego im prawo do korzystania z posługi polskich spowiedników, wywodzących się z innych klasztorów cysterskich ${ }^{9}$. W inwentarzu odnotowano dwa śpiewniki - dary Lengi. Pierwszy z około 1708 roku $^{\text {I0 }}$ otrzymała Zofia Anna Korycińska, późniejsza ksieni trzebnicka ${ }^{\text {II }}$. Drugi ze śpiewników był darem dla

\footnotetext{
4 Autorka inwentarza na podstawie zapisów własnościowych ksiąg znajdujących się w bibliotece parafialnej w Trzebnicy przedstawiła sześć kategorii proweniencji: były to księgi z exlibrisem Praepositurae Trebnicensis, księgi pochodzące z innych bibliotek, księgi przeznaczone przez konwent do użytku ojców duchownych, księgi nabyte przez kaznodziejów i spowiedników, następnie księgi noszące nazwiska lub różne noty własnościowe prywatne oraz najbardziej zasobną kategorię - księgi noszące nazwiska lub dedykacje sióstr zakonnych. Powyższy podział w dużej mierze można zastosować do omówienia ksiąg będących niegdyś w posiadaniu cysterek trzebnickich. Warto zaznaczyć, że Autorka często podawała skrócone tytuły dzieł. W niniejszej pracy będą uwzględnione noty w ich oryginalnym brzmieniu, a także propozycje rozwinięcia abrewiacji, zamieszczone w inwentarzu. Zob. H. Szwejkowska, Biblioteka klasztoru cystersek w Trzebnicy (dalej: Inwentarz), Wrocław 1955, s. 14-15.

5 Inwentarz, s. 8.

6 Zacytowano tekst w polskim XVII-wiecznym przekładzie. Zob. A. M. Wyrwa, Organizacja wewnętrzna w klasztorach cysterek Polskiej Prowincji Cystersów w świetle Statutów Edmunda od Krzyża z 1580 r., w: Cysterki $w$ dziejach i kulturze ziem polskich, dawnej Rzeczypospolitej i Europy Środkowej, red. A. M. Wyrwa, A. Kiełbasa, J. Swastek, Poznań 2004, s. 58.

7 Ufundowany przed 1289 rokiem. Zob. J. Rajman, A. Wolska, M. Wolski, Jemielnica, w: Monasticon Cisterciense Poloniae. Katalog męskich klasztorów cysterskich na ziemiach polskich i dawnej Rzeczypospolitej, t. 2, red. A. M. Wyrwa, J. Strzelczyk, K. Kaczmarek, Poznań 1999, s. 80.

8 Żył w latach 1672-1731. W 1700 roku złożył profesję zakonną w Jemielnicy. Zdaniem H. Gerlica Lenga pełnił funkcję spowiednika w latach 1707-1714. Inaczej przedstawiła to H. Szwejkowska, datując obecność Lengi w klasztorze trzebnickim na lata 1701-1709. Wydaje się, że bardziej prawdopodobne są te pierwsze ustalenia, zgodne z notami w księgach sięgającymi najwcześniej 1708-1709 roku. Zob. H. Gerlic, Cystersi „górnośląscy” spowiednikami cysterek trzebnickich, w: Cysterki $w$ dziejach i kulturze ziem polskich, dawnej Rzeczypospolitej i Europy Środkowej, red. A. M. Wyrwa, A. Kiełbasa, J. Swastek, Poznań 2004, s. 144-145; Inwentarz, s. 46.

9 Pozwoliło to cysterkom na zrzucenie zależności od ojców lubiąskich. Zob. Inwentarz, s. 13.

10 H. Szwejkowska, Rękopisy, w: Biblioteka klasztoru cystersek w Trzebnicy (dalej: Inwentarz, rkps, nr), Wrocław 1955, nr 32.

11 Żyła w latach 1683-1741. W 1718 roku była zakrystianką, następnie pełniła funkcję szafarki, a w końcu, w latach 1727-1741, ksieni. Zasłynęła dzięki swojej działalności fundacyjnej i organizacyjnej, m.in. wybudowała ołtarz w kaplicy św. Jadwigi, jej staraniem powstały Bractwa św. Anny i św. Józefa, dzięki niej w 1729 roku przebudo-
} 
profeski Agnieszki Pawłowskiej ${ }^{12}$, o czym głosi dedykacja - „Przewielebney w Chrystusie Panu Pannie Agnisce zwerbna Pawłoski Zakonu Swiętego Cistercienskiego w Klasztorze Trebnickim Profesce ofiaruie Brat Eugenius Oppatt mp..."13. Następnym darem późniejszego opata była pozbawiona karty tytułowej księga drukowana, zawierająca medytacje rekolekcyjne $^{14}$, a obdarowaną - mniszka Jadwiga Rychłowska ${ }^{15}$. Ze wspomnianym spowiednikiem i opactwem w Jemielnicy można powiązać także rozważania jezuity i pisarza ascetycznego Jakuba Alvareza ${ }^{16}$, przełożone przez Szymona Wysockiego ${ }^{17}$ pod tytułem $O$ żywocie zakonnym...książka... na polskie przez X. Symona Wysockiego... przełożona, które ukazały się w I6I3 roku w krakowskiej oficynie Mikołaja Loba ${ }^{18}$. O przynależności tego dzieła do jemielnickiego księgozbioru klasztornego oraz o zakupie księgi świadczą poniższe zapisy: „M[o]n[astre]rij ${ }^{\text {19 }}$ Gemelnitz SOC. BVM et S. Jacobi Ap[osto]li Major”, „emptus medio flor[eno] p[er] P. [atrem] Eugenium Lenga Prof. Gemelnitz. Confessarium Trebnicensem I709". Oprócz wspomnianego opata Eugeniusza, darczyńcą był także kolejny spowiednik z Jemielnicy, Benedykt Cieszkont ${ }^{20}$. Obdarowaną przez niego była zaś „ $V$. $V$. Marianna Gomolinska ${ }^{21}$ Sen. [?] I778. I8. Julij”.

wano trzebnicki ratusz, postawiono pierwsze murowane domy, w 1734 roku odbudowano pustelnię św. Jadwigi w Lesie Bukowym, ponadto wybudowano stacje drogi krzyżowej, kościół we wsi Kotowice, a także wypoczynkowy pałacyk we wiosce o nazwie Komorówko. Zob. R. Kaczmarek, J. Witkowski, Kaplica św. Jadwigi w Trzebnicy. Wyposażenie i funkcjonowanie od XIII do XVIII w., w: Cysterki $w$ dziejach i kulturze ziem polskich, dawnej Rzeczypospolitej i Europy Środkowej, red. A. M. Wyrwa, A. Kiełbasa, J. Swastek, Poznań 2004, s. 363; A. Kiełbasa, Mecenat polskich ksień cysterek w Trzebnicy, Trzebnica 2010, s. 38-42; M. Borkowska, Skład osobowy polskich klasztorów cysterek w XVII-XVIII wieku, w: Cysterki w dziejach i kulturze ziem polskich, dawnej Rzeczypospolitej i Europy Środkowej, red. A. M. Wyrwa, A. Kiełbasa, J. Swastek, Poznań 2004, s. 70.

12 Żyła w latach ok. 1705-1754. W 1725 roku złożyła profesję zakonną. Zakon cysterek był bardzo popularny w rodzinie Pawłowskich herbu Wierzbno. W klasztorze trzebnickim znalazło swoje miejsce pięć dziewcząt z tej rodziny, a w jego w filiach w Ołoboku i Owińskach, po jednej. Zob. M. Borkowska, Skład osobowy..., s. 62-64, 73.

13 Inwentarz, rkps, nr 33.

14 H. Szwejkowska, Polonica, w: Biblioteka klasztoru cystersek w Trzebnicy (dalej: Inwentarz, druki, nr), Wrocław 1955, nr 38.

15 Żyła w latach około 1709-1787. Zob. M. Borkowska, Skład osobowy..., s. 74.

16 Żył w latach 1560-1620. Pochodził z Toledo. Po ukończeniu studiów i otrzymaniu święceń wykładał filozofię, teologię i Pismo św. w Limie. W 1617 roku został prowincjonałem w Peru. Jego 3-tomowa praca De vita spirituali eiusque perfectione (Lyon 1608) doczekała się wielu wydań i przekładów, w tym wspomnianego powyżej, krakowskiego z 1613 roku. Zob. J. Majkowski, Alvarez de Paz, w: Encyklopedia Katolicka, t. 1, Lublin 1973, kol. $396-397$.

17 Żył w latach 1546-1622. Był studentem Uniwersytetu Krakowskiego. W 1569 roku wstąpił do Towarzystwa Jezusowego. W Szwecji pełnił funkcję spowiednika królowej Katarzyny Jagiellonki i wychowawcy Zygmunta III Wazy. Był kaznodzieją m.in. w Poznaniu, Kaliszu oraz Krakowie, gdzie osiadł później w domu profesów. Tam oddawał się między innymi pracy tłumacza. Oprócz własnej twórczości przetłumaczył łącznie około 30 dzieł religijnych. Była to głównie literatura ascetyczna i żywoty świętych oraz wiadomości z terenów objętych pracą misyjną. Zob. A. P. Bieś, Wysocki Szymon, w: Encyklopedia Katolicka, t. 20, Lublin 2014, kol. 1082; L. Grzebień, Wysocki Szymon, w: Stownik Polskich Teologów Katolickich (dalej: SPTK), t. 4, red. H. E. Wyczawski, Warszawa 1983, s. 486-488.

18 Inwentarz, druki, nr 3.

19 Tu raczej powinno być M[o]n[aste]rij-monasterii.

20 Żył w latach 1712-1780. W 1735 roku złożył profesję zakonną. Funkcję spowiednika trzebnickich cysterek pełnił od 1748 roku aż do śmierci. Był kandydatem na następcę zmarłego opata Eugeniusza Missury w 1763 roku, jednak nie uzyskał zatwierdzenia od króla pruskiego. Zob. H. Gerlic, Cystersi „,górnośląscy”..., s. 149.

21 Wykaz cysterek odnotowuje Mariannę Gomolińską żyjącą w latach ok. 1682-1758. Nie zgadza się to więc z datą podaną w przytoczonym zapisie. Zob. M. Borkowska, Skład osobowy..., s. 68. 
Ponadto z Jemielnicy pochodził również rękopiśmienny kodeks Officia ad Vigilias et Laudes z 1783 roku $^{22}$, zawierający nabożeństwa i modlitwy na święta oraz uroczystości maryjne, sporządzony przez tamtejszego mnicha - „Exarata a religioso fratre ex Professis In solitudine Gemelnicensi" oraz dzieło należące do niezidentyfikowanego spowiednika ${ }^{23}$. Przedstawione wpisy potwierdzają utrzymywanie kontaktów trzebnickiego klasztoru z jemielnickim opactwem, jak i fakt zabierania ze sobą bądź też zaopatrywania się przez spowiedników w potrzebne księgi.

Na wyróżnienie zasługują także pozycje związane z kolejnym klasztorem cysterskim, tym razem w Przemęcie ${ }^{24}$. W inwentarzu znajduje się kilka dzieł autorstwa Kaspra z Przemętu ${ }^{25}$, który, szukając schronienia w czasie najazdu szwedzkiego, poprzez klasztor cystersów w Kamieńcu, dotarł do panien sióstr w Trzebnicy ${ }^{26}$. Tam prawdopodobnie przebywał w latach I655-1664, a jego twórcza działalność dotyczyła głównie rozważań oraz modlitewników przygotowywanych dla zakonnic ${ }^{27}$. Kasper z Przemętu ofiarował mniszce Małgorzacie Rajskiej ${ }^{8}$ Rozmyślania duchowne z I655 roku, zawierające modlitwy oraz rozważania na temat różnych aspektów życia monastycznego ${ }^{29}$. Ponadto prawdopodobnie kontynuował Owoce ćwiczenia duchownego z 1656 roku, autorstwa Wojciecha Kazimierza Jankowskiego, mnicha wągrowieckiego i trzebnickiego kaznodziei ${ }^{30}$. Tematykę tego dzieła, podarowanego siostrze Jadwidze Magdalenie Kołaczkowskiej, stanowiły rozważania dotyczące Boga, natury człowieka i powołania zakonnego ${ }^{31}$. Kolejny z kodeksów autorstwa Kaspra z Przemętu nie posiadał karty tytułowej i zaczynał się od rozdziału Na dzięn Zmartwystania Panskiego: Rozmyslanie ${ }^{32}$. Na końcu umieszczono napis „Laus Deo opt.[imo] Max[imo]: B.V.M. I656 in exilio in Monasterio Ducali in Camencz". Tenże modlitewnik powstawał przez dwa lata - pierwsza część została napisana w I656 roku, kiedy to Kasper przebywał w Kamieńcu Ząbkowickim, a druga w następnym roku (prawdopodobnie w Trzebnicy), o czym świadczy napis „Roku Pańskiego I657. 26. maji. Pr. Gaspar, Professus Premetensis mpp.”’3.

22 Inwentarz, rkps, nr 42.

23 „P... Prof. Gemel[nicensis] Conf:[essarius] Monial.[ium] Trenitii [sic!] 1783”. Z uwagi na wspomnianą datę, właścicielem księgi mógł być Bernard Ivand, pełniący posługę wśród cysterek w latach 1782-1810. Zob. Inwentarz, druki, nr 42; H. Gerlic, Cystersi , górnoślassy”..., s. 150-151.

${ }^{24}$ W Przemęcie znajdowało się opactwo cystersów z kościołem parafialnym pod wezwaniem św. Jana Chrzciciela, zbudowanym w latach 1651-1690. Zob. T. Sobera, Przemęt, w: Encyklopedia Katolicka, t. 16, Lublin 2012, kol. 642.

25 Tenże zakonnik przygotował dla mniszek kilka kodeksów, a w niektórych zaznaczył swoją obecność. Zob. Inwentarz, rkps, nr 18, 19, 20, 21, 22; tamże s. 66.

26 A. Sutowicz, Dorobek rękopiśmienny śląskich klasztorów żeńskich (XIII-XVIII w.), „Wrocławski Przegląd Teologiczny", 16/2008, nr 2, s. 172.

27 Inwentarz, s. 39, przyp. 84.

${ }^{28}$ W 1639 roku złożyła profesję zakonną. W 1653 roku ufundowała główny ołtarz kaplicy św. Jadwigi. Zmarła w 1664 roku. Zob. R. Kaczmarek, J. Witkowski, Kaplica św. Jadwigi..., s. 357; M. Borkowska, Skład osobowy..., s. 74 .

29 Inwentarz, rkps, nr 18.

30 Inwentarz, rkps, nr 19. Napisane łącznie przez trzech autorów.

31 Żyła w latach ok. 1632-1696. Chórowa, pełniła funkcję bursarii. Kołaczkowska w 1689 roku przekazała księgę do biblioteki klasztornej. Zob. M. Borkowska, Skład osobowy ..., s. 70; Inwentarz, rkps, nr 19.

${ }^{32}$ Inwentarz, rkps, nr 20.

${ }^{33}$ Treść tego zabytku poświęcono medytacjom, przygotowanym na bazie tekstu Ewangelii, które obejmowały okres od Wielkanocy do okresu zwykłego po Zielonych Świątkach, oraz rozważaniom na dni wspomnień świętych. Zob. A. Sutowicz, Polska książka ..., s. 359-360; Inwentarz, rkps, nr 20. 
Kolejne dzieło autorstwa Kaspra z Przemętu także było pozbawione karty tytułowej, a rozpoczynały je rozważania $N a$ Dzięn $S$. Andrzeja, prawdopodobnie przeznaczone dla cystersów z Przemętu lub Kamieńca ${ }^{34}$. H. Szwejkowska wykazała jego podobieństwo do przedstawionych już wcześniej rozważań. Prawdopodobnie więc kodeksy te stanowiły odpisy - jeden powstał dla cystersów, o czym świadczą stosowane męskie formy gramatyczne, a drugi został dostosowany dla mniszek ${ }^{35}$. Ponadto Kasper z Przemętu spisał dla użytku trzebnickiego konwentu regułę św. Benedykta na polecenie profeski Jadwigi Kłobuczyńskiej, opatrzoną tytułem Przemowa Swiętego Oyca Benedicta Opata Ktora Czyni Do Zakonnych Corek na Regułe Swoię, umieszczając w niej podpis „F.P. Gaspar scripsit Professus Premeten: $S$. O. Cister.' ${ }^{36}$. Podsumowując związki z klasztorem cystersów w Przemęcie, można jeszcze wskazać na dzieło Franciszka Costera w przekładzie Piotra Skargi, zatytułowane O czterech końcach ostatnich żywota ludzkiego, które ukazało się w I606 roku w oficynie Andrzeja Piotrkowczyka. O jego pierwotnej przynależności do biblioteki klasztornej w Przemęcie świadczy zapis własnościowy „Ex libris M[onaste]ry Praemetensis”37.

Warto również zwrócić uwagę na kilka pozycji, które świadczą o utrzymywaniu kontaktów z Trzebnicą przez mniszki z wielkopolskiej filii w Owińskach. Zakonnica owińska, Elżbieta Apolinara Bułakowska ${ }^{38}$, ,Naznak nigdy niedmięnnego z sczyro zyczliwego Afektu”, ofiarowała profesce trzebnickiej, Ludmile Bnińskiej39, dzieło Jana Morawskiego Ambona Ducha $S$. do Serca mówiącego ${ }^{40}$. Inna księga ${ }^{41}$ była darem Jadwigi Teresy Kozielskiej² dla profeski trzebnickiej, Jadwigi Magdaleny Kołaczkowskiej. Kolejna zaś ${ }^{43}$ przeszła z rąk Katarzyny Petroneli Włostowskiej ${ }^{44}$ do mniszki trzebnickiej, Barbary Grodzińskiej ${ }^{45}$. Jedną z ksiąg otrzymała także Konstancja Leszczyńska ${ }^{46}$, którą dała jej „,do czwiczenia Duchownego Zyczliwa ciotka Katarzyna Sokołowska ${ }^{47}$ Z O[wińska]"'48. Do księgozbioru trzebnickiego

\footnotetext{
34 Inwentarz, rkps, nr 21.

35 A. Sutowicz, Polska książka..., s. 360-361.

36 Inwentarz, rkps, nr 22.

37 Inwentarz, druki, nr 16.

38 Chórowa. Zmarła przed 1731 rokiem. Zob. M. Borkowska, Leksykon zakonnic polskich epoki przedrozbiorowej, t. 1, Warszawa 2004, s. 72.

39 Żyła w latach ok. 1674-1738. Chórowa, od 1706 roku występowała jako szafarka, a w 1718 roku jako kantorka. Zob. M. Borkowska, Skład osobowy..., s. 67.

40 Inwentarz, druki, $\mathrm{nr} 41$.

41 Inwentarz, druki, nr 21.

42 Chórowa. Zob. M. Borkowska, Leksykon zakonnic..., s. 71.

43 Inwentarz, druki, nr 51.

44 Córka Dawida Włostowskiego i Katarzyny Skrzetuskiej. Miała czwórkę rodzeństwa, w tym brata Wojciecha Ignacego, który wstąpił do klasztoru cystersów w Lądzie. W 1644 roku wzmiankowano ją już jako zakonnicę. Zob. M. Borkowska, Leksykon zakonnic..., s. 71.

45 Chórowa i wieloletnia, gorliwa kantorka. Zmarła w 1689 roku. Zob. M. Borkowska, Skład osobowy..., s. 69.

46 Córka wojewody łęczyckiego Wacława (Władysława?) i Barbary Walewskiej. Jeden z jej braci wstąpił do kamedułów, drugi zaś został opatem czerwińskim. Chórowa, pełniła funkcję bursarii. Zmarła w 1714 roku. Zob. M. Borkowska, Skład osobowy..., s. 71.

47 Prawdopodobnie córka kasztelana gostyńskiego Mikołaja i Barbary Szczawińskiej. Miała dwie siostry Elżbietę i Zofię, które wstąpiły do norbertanek w Strzelnie. Zob. M. Borkowska, Leksykon zakonnic ..., s. 71.

48 Inwentarz, druki, nr 23.
} 
trafiła jeszcze kolejna księga, początkowo będąca w posiadaniu ksieni owińskiej, Agnieszki Modrzewskiej49.

W inwentarzu można także wyróżnić pojedyncze woluminy pochodzące z różnych klasztorów. W jednej z ksiąg drukowanych widnieje wpis własnościowy kolegium jezuickiego w Poznaniu. Było to dzieło Franciszka Ariasa ${ }^{50}$ Zdrój wody żywej abo ćwiczenie... o przytomności Bożej... (przekład Szymona Wysockiego), wydane w I6II roku w krakowskiej oficynie Jana Szarffenbergera ${ }^{51}$. W tym przypadku zapis brzmiał „Coll posn Soc Jesu pro Infirm. I642", a zatem pierwotnie księga była przeznaczona do biblioteki infirmerii, gromadzącej z reguły dzieła ascetyczne, mające ułatwiać chorym powrót do zdrowia ${ }^{52}$. Następnie w dziele Marcina Bogumiła Grymosza ${ }^{53}$, Szczere samego Pana Boga szukanie, wydanym w I689 roku przez oficynę cystersów w Oliwie ${ }^{54}$, czterokrotnie powtórzono zapis własnościowy „Wielebn[ego] Zgromadz[enia] Zakonn[ego] PP. Bernardynek w Poznaniu”. Kolejna zaś z ksiąg prowadzi do kaliskich klarysek. Dzieło Adriana Miaskowskiego ${ }^{55}$ pt. Niemylna do zbawienia drog $a^{56}$, podpisała tamtejsza mniszka, ,Dorota Katarzyna Tyminiecka ${ }^{57}$ Zakonnica Fanciska (sic!) S. Matki S Klary. Mystrzyni PP siostr młodych Zakonnych", i podarowała je mniszce trzebnickiej, Teresie Bułakowskiej ${ }^{8}$. Widać ponadto zapisy własnościowe w księdze Poseł boskiej łaskawości..., w przekładzie Jakuba Gawatha z I648 roku5, zgodnie z którymi, zanim weszła ona w skład „Xiąszki z libriey Trzebnicki”, należała do biblioteki klasztoru cystersów w Lądzie - „liber monasteris landen(c)es”. Ponadto dzieło Jana Morawskiego Duchowna teologia... z I695 roku ${ }^{60}$, pierwotnie wchodziło w skład biblioteki klasztoru

\footnotetext{
49 Inwentarz, druki, nr 10. Początkowo miała wstąpić do benedyktynek, zreformowanych przez Magdalenę Mortęską. Ostatecznie dołączyła do panien sióstr cysterek owińskich, gdzie była chórową, a w 1649 roku pełniła już funkcję ksieni. Zob. M. Borkowska, Leksykon zakonnic..., s. 71.

50 Żył w latach 1533-1605. Był teologiem i pisarzem ascetycznym. Do Towarzystwa Jezusowego wstąpił w 1561 roku. Jego dzieła były wielokrotnie wydawane i doczekały się licznych tłumaczeń. Zob. J. Majkowski, Arias Franciszek, w: Encyklopedia Katolicka, t. 1, Lublin 1973, kol. 916.

51 Inwentarz, druki, nr 6.

52 L. Piechnik, Organizacja bibliotek jezuickich w Polsce od XVI do XVIII wieku, „Archiwa, Biblioteki i Muzea Kościelne", 30/1975, s. 263.

53 Żył w latach 1633-1708. Wstąpił do Towarzystwa Jezusowego w 1651 roku. Wykładał nauki humanistyczne, retorykę, filozofię i teologię moralną m.in. w Lublinie, Poznaniu, Kaliszu i Krakowie. Był teologiem i autorem dzieł ascetycznych, w tym rozważań rekolekcyjnych przeznaczonych dla zakonnic, a także dzieł mariologicznych. Zob. E. Pohorecki, Grymosz Marcin Teofil, w: Encyklopedia Katolicka, t. 6, Lublin 1993, kol. 256.

54 Inwentarz, druki, nr 30.

55 Żył w latach 1657-1737. Uczył się retoryki w poznańskim kolegium jezuickim. Do Towarzystwa Jezusowego wstapił w 1672 roku w Krakowie. Studia filozoficzne ukończył w Kaliszu, zaś teologiczne w Poznaniu. Święcenia kapłańskie otrzymał w 1685 roku. Wykładał matematykę, filozofię i teologię dogmatyczną. Pełnił funkcję rektora kolegiów w: Poznaniu w latach 1703-1706 i 1712-1717, w Krakowie w latach 1706-1708 i 1721-1726 oraz w Jarosławiu od 1717 do 1721 roku. Był też m.in. prefektem studiów w Poznaniu i Krakowie. Pisał dzieła z zakresu życia duchowego i filozofii. Zob. E. Ziemann, Miaskowski Adrian, w: Encyklopedia Katolicka, t. 12, Lublin 2008 , kol. 767-768; L. Grzebień, Miaskowski Adrian, w: SPTK, t. 3, red. H. E. Wyczawski, Warszawa 1982, s. 100-101.

56 Inwentarz, druki, nr 39.

57 Tymieniecka. Córka Władysława, burgrabiego ostrzeszowskiego i Urszuli Bąkowskiej. Zmarła w 1740 roku. Zob. M. Borkowska, Leksykon zakonnic..., s. 50.

58 W 1686 roku złożyła profesję zakonną. Chórowa, infirmerka, a w 1718 roku występowała jako dispensatrix. Zmarła w 1726 roku. Zob. M. Borkowska, Skład osobowy..., s. 67.

59 Inwentarz, druki, nr 28.

60 Inwentarz, druki, nr 44.
} 
cystersów w Rudach ${ }^{61}$ - „Monasterii Raudensis Sac. Cist. Ordinis”, a księga liturgiczna Rituale Cisterciensium z 1573 roku$^{62}$, w klasztorze cystersów w Lubiążu. Warto także wspomnieć o darze o. reformata Archanioła Sarnowskiego, prowincjała prowincji wielkopolskiej, dla trzebnickiego kaznodziei Łukasza Gleitzla ${ }^{63}$, a także o druku należącym do profesa Józefa z Henrykowa ${ }^{64}$.

Kolejna grupa wpisów informuje o przynależności danych ksiąg do biblioteki trzebnickiej, a zatem przeznaczonych do użytku wspólnego całego konwentu. Tego rodzaju noty występują w wielu formach: Xięgi zlibryiey Trzebnicki ${ }^{65}$, Zlibryey Trzebnicki ${ }^{66}$, Xiąszki zlibrii trzebniczki $^{67}$, z libryi Trzebnicki ${ }^{68}$, Xieki zlibryieij ${ }^{69}$, Xięgi zlibryei Trzebnicki ${ }^{70}$, Xioszki zlibriey Trzebnicki ${ }^{71}$, xiąszki z libriey Trzebnicki ${ }^{72}, X$ z libryi Trzebnicki ${ }^{73}$, Xiązki z libry Trzebnicki74, Xięga z libryi Trzebnicki ${ }^{75}$, po prostu z Libryiey ${ }^{76}$, z Biblotyki Trzebnicki77, Zlibryi Trzebnicki $^{78}$, Xiaszki zlibriey ${ }^{79}$, Xiegi zlibriy Trebnic ${ }^{80}$, a także w języku niemieckim - auss der trebnitzer bibloteke ${ }^{81}$ oraz tröbnitzer biliotöcke (sic!) ${ }^{82}$. Warto zauważyć, że powyższe wpisy mogą także stanowić ciekawy materiał z punktu widzenia rozwoju języka polskiego.

Księgozbiór powiększał się również dzięki przejmowaniu ksiąg po zmarłych mniszkach. W takich przypadkach zapisy wyglądały następująco: „Popannie Malachoski do libryey

\footnotetext{
${ }^{61}$ Klasztor ufundowano w 1252 lub 1255 roku z inicjatywy księcia opolskiego Władysława. Kilkadziesiąt lat później założono filię w Jemielnicy. Do 1552 roku konwent rudecki podlegał opactwu jędrzejowskiemu, a następnie prowincji czeskiej. Czasy jego świetności przypadły na rządy opata A. E. Pospela (1648-1679). Klasztor uległ kasacie w 1810 roku. Zob. A. Barciak, J. Gorzelik, Woszczyce-Rudy, w: Monasticon Cisterciense Poloniae. Katalog męskich klasztorów cysterskich na ziemiach polskich i dawnej Rzeczypospolitej, t. 2, red. A. M. Wyrwa, J. Strzelczyk, K. Kaczmarek, Poznań 1999, s. 361-362; J. Nastalska-Wiśnicka, Rudy Wielkie, w: Encyklopedia Katolicka, t. 17, Lublin 2012, kol. 558-559.

62 Inwentarz, rkps, nr 9.

${ }^{63}$ H. Szwejkowska, Druki z bibliotek obcych, mające noty rękopiśmienne, dotyczące Trzebnicy (dalej: Inwentarz, druki z notami rękopiśmiennymi, nr), w: Biblioteka klasztoru cystersek w Trzebnicy, Wrocław 1955, nr 2.

${ }^{64}$ H. Szwejkowska, Druki obce, w: Biblioteka klasztoru cystersek w Trzebnicy (dalej: Inwentarz, druki obce, nr), Wrocław 1955, nr 1.

65 Inwentarz, rkps, nr 20.

66 Inwentarz, rkps, nr 22.

67 Inwentarz, druki, nr 7.

68 Inwentarz, druki, nr 11.

69 Inwentarz, druki, nr 19.

70 Inwentarz, druki, nr 20.

${ }^{71}$ Inwentarz, druki, nr 27.

72 Inwentarz, druki, nr 28.

73 Inwentarz, druki, nr 36.

74 Inwentarz, druki, nr 45.

75 Inwentarz, druki, nr 46.

76 Inwentarz, druki, nr 49.

77 Inwentarz, druki, nr 50.

78 Inwentarz, druki, nr 59.

79 Inwentarz, druki, nr 69.

80 Inwentarz, druki obce, $\mathrm{nr} 22$.

81 Inwentarz, druki obce, nr 29.

82 Inwentarz, rkps, nr 18.
} 


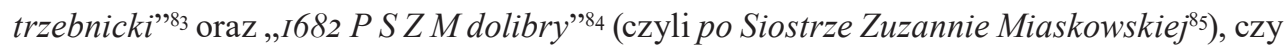
też w zbliżonym brzmieniu - „I682 po S Z M dolibriey Trzebnicki”86. Niekiedy uzupełniały go także zapisy samych cysterek, a przykładowy brzmiał: „Daię tę xięgę do Biblotky Trzebni[c] kiey do uzywania siostrom zakonnym w R.P. I689 Jadwyga Magdalena Kołaczkowska"87. Zasób ksiąg wzbogacała niekiedy sama ksieni, m.in. Krystyna Katarzyna Pawłowska ${ }^{88}$, która w I688 roku dała ,tę ksiazkę do librrey Christina Pawłowska A T." "89. Ponadto własnym sumptem zbiory klasztorne uzupełniła ksieni Bernarda Paczyńska, która za kwotę blisko 50 florenów nabyła rękopiśmienne Martyrologium des Heiligen z I759 roku ${ }^{\circ \circ}$, zgodnie z zapisem: „Hic Liber sumptibus Reverendissimae Dominae Abbatissae Bernardae comparatus est”.

Na podstawie różnego rodzaju wpisów można także wyszczególnić księgi przeznaczone dla konwentu i osobne, indywidualne dary dla mniszek. W tej grupie należy wyróżnić dar Macieja Tretera $^{91}$ z I664 roku „Pro Conventu Trebnicensi”. Księga trafiła następnie do mniszki trzebnickiej Benedykty Rajskiej ${ }^{22}$, która sprawiła ją „,dla panięnek co się do zakonu czwiczą"93. W tym samym roku Maciej Treter przeznaczył „Pro Conventu Trebnicensi” jeszcze jedną księgę drukowaną94. W bliżej nieznany sposób ofiarowano także mniszkom Missae pro defunctis z I79I roku ${ }^{95}$, o czym świadczy zapis w języku polskim: „Ten Mszalik do Trzebnicy oddać do Panien Zakonnych".

Na podstawie inwentarza można wyróżnić także księgi, które były prezentowane poszczególnym ksieniom. W i688 roku karmelitanka bosa Agnieszka ofiarowała ksieni Katarzynie Pawłowskiej z Wierzbna dzieło jednego z najwybitniejszych karmelitańskich autorów, o. Bonawentury od św. Stanisława (Frezera) ${ }^{96}$, zwracając się do niej słowami: „Moiey w Bogu Namilszey Matce y Dobrodzieyce”"97. Następną obdarowaną była Jadwiga

\footnotetext{
83 Inwentarz, druki, nr 31.

84 Inwentarz, druki, nr 54.

85 Szlachcianka herbu Bończa. W 1667 roku złożyła profesję zakonną. Chórowa. Zmarła w 1681 roku. Zob. M. Borkowska, Skład osobowy..., s. 72.

86 Inwentarz, druki, nr 58.

87 Inwentarz, rkps, nr 19.

${ }^{88}$ Ksieni w latach 1674-1699. Zob. R. Kaczmarek, J. Witkowski, Fundacje artystyczne opatki trzebnickiej Krystyny Katarzyny z Wierzbna Pawłowskiej, w: Historia i kultura cystersów w dawnej Polsce i ich europejskie związki, red. J. Strzelczyk, Poznań 1987, s. 453-454.

89 Inwentarz, druki, nr 63.

90 Inwentarz, rkps, nr 38.

91 Urodził się w 1623 roku w Poznaniu. Historyk, wydawca. Brat Szymona Aleksego, prepozyta warmińskiego. Jego stryjecznym dziadkiem był Tomasz Treter, kanonik warmiński. Uczył się w Poznaniu u jezuitów, a następnie studiował na Uniwersytecie Krakowskim, gdzie wykładał od 1651 roku. Wydawał panegiryki i dzieła swego wuja, Tomasza. Zob. H. E. Wyczawski, Treter Maciej Kazimierz, w: SPTK, t. 4, s. 344.

92 Około 1650 roku własnym kosztem odnowiła ołtarz św. Jadwigi. Zob. M. Borkowska, Skład osobowy..., s. 74.

93 Inwentarz, druki, nr 34.

94 Inwentarz, druki, nr 66.

95 Inwentarz, druki, nr 40.

96 W. Graczyk, Księgozbiór klasztoru-eremu karmelitów bosych w Czernej od XVII do końca XIX wieku. Studium z dziejów kultury intelektualnej i duchowej, Kraków 2011, s. 186.

97 Inwentarz, rkps, nr 24.
} 
Pruszakówna $^{98}$, która otrzymała księgę $e^{99}$ od mniszki Katarzyny Anny Gałczyńskiej ${ }^{100}$, zwracającej się do niej osobliwie: ,ia katarzina anna gatczinska daruię tę x[ięgę] imosci pannie Jadwidze pruszakownie moiey fritcze napaniat[kę] izebi bila moia fritka ia[ż] do smierczi". Na tym przykładzie widać, że podarowana księga potrafiła być wyrazem bliskich i serdecznych relacji.

W inwentarzu znalazły się także dzieła bezpośrednio dedykowane poszczególnym ksieniom, o których wspominano już wcześniej. W ramach tej kategorii można wskazać na druk muzyczny dedykowany ostatniej ksieni Dominice von Giller ${ }^{10}$. Drukowane dedykacje były poświęcone również: Zofii Annie Korycińskiej ${ }^{102}$, Katarzynie Zuzannie Kopytlańskiej ${ }^{103}$, Benedykcie Mariannie Biernackiej ${ }^{104}$, Bernardzie Paczyńskiej ${ }^{105}$ oraz Krystynie Katarzynie Pawłowskiej ${ }^{\text {106 }}$. Warto przy tym zaznaczyć, że były to dzieła o charakterze ascetycznym, a także hagiograficznym.

Jedną z następnych grup ksiąg stanowią dary przeznaczone dla samych mniszek trzebnickich. Wspomniano już o darze kaliskiej klaryski Doroty Katarzyny Tymienieckiej ${ }^{107}$. Niejaki Johann Zausladen podarował swojej przyjaciółce, Scholastyce Hraback, jedno z dzieł zawierające rozważania na cały rok, kierując do niej słowa: „Meiner Wurdigsten Freudinn Scholastica zum immerwaehrenden Andenken"108. Podobnie ksieni Krystyna Katarzyna Pawłowska obdarowała siostrę Beatrix Franciszkę Trzebińską ${ }^{109}$, prosząc „aby się zamnie modlita teraz y posmierci pamiętała nadusze moie" ${ }^{\text {"II }}$. Natomiast benedyktynka Jadwiga Rokoseska przekazała Dyscypliny duszne Kaspra Drużbickiego ${ }^{\text {III }}$ pannie siostrze trzebnickiej Ewie Pawłowskiej ${ }^{\mathrm{II}}$, aby ta "te dyscyplinke y zobraskiem Przyiena anamnie uboga Pamientała yteras I Posmierci".

Na podstawie zapisów własnościowych można wskazać grupę ksiąg, których właścicielkami były same ksienie. Do Krystyny Katarzyny Pawłowskiej należała Modlitwa Pańska, autorstwa Marcina Bogumiła Grymosza ${ }^{113}$, do Jadwigi Pruszakówny - przekład dzieła Ro-

\footnotetext{
98 Właściwie Magdalena Bieniewska. Urodziła się około 1622 roku. Profesję zakonną złożyła w 1622 roku. Chórowa, przeorysza, a od 1659 roku ksieni. Zmarła w 1674 roku w Poznaniu. Zob. M. Borkowska, Skład osobowy..., s. 67.

99 Inwentarz, druki obce, $\mathrm{nr} 20$.

100 Być może chodziło o zmarłą w 1686 roku bernardynkę wieluńską. Zob. M. Borkowska, Leksykon zakonnic..., s. 210 .

101 Inwentarz, rkps, nr 46.

${ }^{102}$ H. Szwejkowska, Wydawnictwa poświęcone przez autorów zakonnicom trzebnickim (dedykacje drukowane) (dalej: Inwentarz, druki dedykowane, nr), w: Biblioteka klasztoru cystersek w Trzebnicy, Wrocław $1955, \mathrm{nr} 1$.

${ }_{103}$ Inwentarz, druki dedykowane, nr 2.

104 Inwentarz, druki dedykowane, nr 3, 4.

105 Inwentarz, druki dedykowane, $\mathrm{nr} 5$.

106 Inwentarz, druki dedykowane, nr 6.

${ }^{107}$ Inwentarz, druki, nr 39.

108 Inwentarz, druki obce, $\mathrm{nr} 8$.

109 Urodziła się ok. 1665 roku. Chórowa, w aktach z 1718-1728 roku występowała jako podprzeorysza, a od 1741 roku jako przeorysza. Zob. M. Borkowska, Skład osobowy..., s. 75.

${ }^{110}$ Inwentarz, rkps, nr 12.

111 Inwentarz, druki, nr 25

${ }^{112}$ Urodziła się ok. 1664 roku. Chórowa, westiarka, a także kapelanka ksieni w 1706 roku. Miała siostrę Teresę Elżbietę, dominikankę poznańską. Zmarła w 1735 roku. Zob. M. Borkowska, Skład osobowy..., s. 73.

113 Inwentarz, druki, nr 29.
} 
berta Bellarmina Wzdychanie gołębice abo o dobru łez zbawiennych księgi troje... " ${ }^{\mathrm{I4}}$, z kolei ksieni Benedykta ${ }^{15}$ posiadała Die Psalmen Davidis ${ }^{\mathrm{II}}$, podpisane „Benedicta Abbatissa I72I" oraz Rok niebieski albo przewodnik do szczęśliwej wieczności Jana Nadasiego ${ }^{\text {II7 }}$. Natomiast Zofia Kawecka ${ }^{\text {II8 }}$ była właścicielką dzieła Przyjaciel $w$ ostatniej potrzebie doznany, albo Bractwo Najświętszego Odkupiciela Ukrzyżowanego ${ }^{\amalg 1}$.

Kolejną - i co warto zaznaczyć - najbardziej liczną kategorię, stanowiły księgi należące do poszczególnych mniszek trzebnickich. Na podstawie zapisów własnościowych można ustalić, że Jadwiga Rokicka ${ }^{120}$ posiadała księgę rękopiśmienną zawierającą rozmyślania duchowe Kaspra z Przemętu ${ }^{121}$, a kolejny kodeks tego autora ${ }^{122}$ był w posiadaniu Katarzyny Rajskiej $^{123}$. Natomiast wspomniana powyżej Zuzanna Miaskowska była właścicielką dzieła Androcego Fulviusa, Ścieszka pobożnego chrześcijanina... ${ }^{\text {I24 }}$. Z kolei Affekty i akty serdeczne miłości Bożej... ${ }^{125}$ opatrzone zapisem - „Siostry Constanciy ta xiązeczka”, zapewne należały do Konstancji Miaskowskiej ${ }^{126}$. W dalszej kolejności trafiły do rąk Elżbiety Masłowskiej ${ }^{127}$.

Imieniem i nazwiskiem, w dziele Franciszka Ariasa Trzy traktaty duchowne ${ }^{128}$, podpisała się Jadwiga Magdalena Kołaczkowska, a Marianna Teresa Jemiołkowska ${ }^{129}$ w dziele Bonawentury Siewierzanina, Psatterz Naświętszej P. Mariej... ${ }^{130}$, który następnie trafił do Anny Roznowskiej ${ }^{131}$. Wspomniana „Maryanna Teresa Imiałkowska Z T. [Zakonnica Trzebnicka]” podpisała również Żywot Pana i Boga naszego Jezusa Chrystusa św. Bonawentury ${ }^{132}$, którego

\footnotetext{
114 Inwentarz, druki, nr 8. Księga ta weszła następnie w posiadanie profeski Barbary Jadwigi Pruszakówny, zapewne krewnej ksieni Jadwigi.

115 Właściwie Marianna Biernacka. Ksieni w latach 1718-1726. Zob. M. Borkowska, Skład osobowy..., s. 67.

116 Inwentarz, druki obce, nr 14.

117 Inwentarz, druki, nr 49.

118 Imię zakonne Kunegunda. Urodziła się około 1648 roku. W 1665 roku złożyła profesję zakonną. Chórowa. Ksieni w latach 1699-1705. Zob. M. Borkowska, Skład osobowy..., s. 69.

119 Inwentarz, druki, nr 56.

${ }^{120}$ Cecylia Rokicka, chórowa. Od 1725 roku aż do śmierci pełniła funkcję przeoryszy. Zmarła w 1727 roku. Zob. M. Borkowska, Skład osobowy ..., s. 74.

121 Inwentarz, rkps, nr 18.

122 Inwentarz, rkps, nr 20

123 Chórowa. Wymieniona w gronie elektorek w 1642 i 1652 roku. W 1653 roku była wzmiankowana jako przeorysza. Zmarła w 1669 roku. Zob. M. Borkowska, Skład osobowy..., s. 74.

124 Inwentarz, druki, nr 4.

125 Inwentarz, druki, nr 2.

126 Na końcu Affektów podpisała się właśnie „Siostra Constancia Miaskoska”. Jednakże wykaz cysterek z polskich klasztorów odnotowuje jedynie Zuzannę Miaskowską, zmarłą w 1681 roku. Zob. M. Borkowska, Skład osobowy..., s. 72 .

127 W 1653 roku złożyła profesję zakonną. Chórowa, a od około 1682 roku kapelanka ksieni. Zmarła w 1708 roku. Zob. M. Borkowska, Skład osobowy..., s. 72.

128 Inwentarz, druki, nr 5.

${ }^{129}$ W 1653 roku złożyła profesję zakonną. Chórowa, pełniła funkcję przeoryszy za rządów ksieni Pawłowskiej i Kaweckiej. Około 1682 roku była mistrzynią nowicjatu, a w 1699 i 1705 roku została dwukrotnie wybrana na urząd ksieni. Odrzucona przez biskupa z powodu polskiego pochodzenia, została obłożona karą ekskomuniki i więzienia. Zob. M. Borkowska, Skład osobowy..., s. 69.

${ }^{130}$ Inwentarz, druki, nr 10.

131 Nie widnieje w wykazie cysterek M. Borkowskiej.

132 Inwentarz, druki, nr 12.
} 
kolejną właścicielką była Ludwika Bnińska ${ }^{\mathrm{I} 33}$, a także Drogę doskonałości chrześcijańskiej... na trzy części rozłożoną ${ }^{\mathrm{I} 4}$.

Wymieniona wyżej Ludwika Bnińska podpisała także Kalwarię albo nowe Jeruzalem na polach zebrzydowskich zasadzone ${ }^{\mathrm{I3} 5}$ jako „Ludomilla Bnińska, Zakonu S. Cistercien w Trzebnicy Professa:...", natomiast Zofia Wierzchlejska ${ }^{136}$ dzieło pt. Uwagi chrześcijańskie na każdy dzień miesiaca ${ }^{137}$. W gronie mniszek właścicielek ksiąg znalazła się także Zofia Czyżewska ${ }^{138}$ z dziełem Stanisława Brzechwy ${ }^{139}$, Najprzewielebniejsza w Bogu Panna Magdalena Mortęska ${ }^{10}$ oraz Mikołaja Mościckiego ${ }^{141}$ Elementarzyk ćwiczenia duchownego... ${ }^{142}$. Kolejna z panien sióstr, Elżbieta Krasnosielska ${ }^{143}$, cieszyła się lekturą Praktyki dobrej śmierci... ${ }^{\mathrm{I} 44}$, a Regina Bolikowska ${ }^{\mathrm{I} 45}$, Nauki pobożności stużacej... ${ }^{146}$ oraz Fortki niebieskiej. Abo ćwiczenie duchowne ${ }^{\mathrm{I} 47}$.

Dyscypliny duszne ${ }^{\mathrm{I4} 8}$ Kaspra Drużbickiego podpisała bliżej nieznana Krystyna Swarcowna, zaś Barbara Grodzińska ${ }^{149}$ Ćwiczenie, którym się wzbudzać mamy do miłości Boga ... ${ }^{150}$, a także dzieło Adama Opatowiusza'51, pt. Poset zbawienia, panien zakonnych klasztoru świętego

133 Przyjęła imię zakonne Ludmiła. Żyła w latach ok. 1674-1738. Chórowa, szafarka i kantorka. Zob. M. Borkowska, Skład osobowy..., s. 67.

134 Inwentarz, druki, $\mathrm{nr} 23$

135 Inwentarz, druki, nr 26.

136 Chórowa i szafarka. Zmarła w 1707 roku. Zob. M. Borkowska, Skład osobowy..., s. 76.

137 Inwentarz, druki, nr 13.

138 Żyła w latach ok. 1722-1782. Chórowa. Zob. M. Borkowska, Skład osobowy..., s. 68.

139 Żył w latach 1587-1649. Wstąpił do Towarzystwa Jezusowego w Krakowie w 1607 roku. Studiował teologię w Rzymie, był rektorem kolegiów jezuickich w Lublinie, Bydgoszczy i Toruniu. W Kaliszu wykładał filozofię. Autor dwóch biografii: Magdaleny Mortęskiej oraz Zofii z Tylickich Tomickiej. Zob. L. Grzebień, Brzechwa Stanisław, w: Encyklopedia Katolicka, t. 2, Lublin 1976, kol. 1123; L. Grzebień, Brzechwa Stanisław, w: SPTK, t. 1, red. H. E. Wyczawski, Warszawa 1981, s. 234-235.

140 Inwentarz, druki, nr 15.

141 Żył w latach 1559-1632. Studia filozoficzno-teologiczne odbył w Krakowie, po czym w celu kontynuowania nauki wyjechał do Bolonii. Wróciwszy do Rzeczpospolitej, uzyskał w studium dominikańskim w Krakowie stopień bakałarza, a następnie doktora teologii. Później wykładał tu teologię kazuistyczną i moralną. Był nominowany na przeora lwowskiego i wikariusza ruskiej prowincji. Jego prace cieszyły się dużą poczytnością. Należał do jednych z pierwszych teologów polskich, którzy pisali dzieła z zakresu ascetyki w języku polskim. Zob. E. Ozorowski, Mikołaj z Mościsk, w: SPTK, t. 3, s. 118-120.

${ }^{142}$ Inwentarz, druki, $\mathrm{nr} 48$.

143 Chórowa, a w 1699 roku wzmiankowana jako zakrystianka. Zmarła w 1727 roku. Zob. M. Borkowska, Skład osobowy..., s. 70 .

${ }^{144}$ Inwentarz, druki, nr 17.

145 Prawdopodobnie krewna ksieni Barbary Bolikowskiej. Chórowa, bursaria, a od około 1682 roku przeorysza. Zob. M. Borkowska, Skład osobowy..., s. 67.

146 Inwentarz, druki, nr 18.

${ }^{147}$ Inwentarz, druki, $\mathrm{nr} 65$.

148 Inwentarz, druki, nr 24.

149 Chórowa, wieloletnia kantorka. Zmarła w 1689 roku. Zob. M. Borkowska, Skład osobowy..., s. 69.

150 Inwentarz, druki, nr 32.

151 Żył w latach 1574-1647. Był studentem Akademii Krakowskiej. Doktorat z teologii uzyskał na Uniwersytecie Sapienza w 1619 roku. Trzykrotnie pełnił funkcję rektora Akademii Krakowskiej. Autor komentarzy do Summy Tomasza z Akwinu, a także dzieł hagiograficznych i ascetycznych. Zob. E. Kasjanuk, Opatowski Adam, w: Encyklopedia Katolicka, t. 14, kol. 613-614. 
Andrzeja adwentowe nabożeństwo podawający ${ }^{152}$. Inna z mniszek, Marianna Gomolińska, była w posiadaniu Źwierciadła przykładów z różnych pisarzów wyjętych ${ }^{153}$ oraz Zabaw duchownych... (z przydaniem różnych godzinek litanij przez Wojciecha Dziedzica zebra$n y c h . ..)^{154}$, a imię wspomnianej wcześniej, szlachetnie urodzonej Konstancji Leszczyńskiej widnieje w kolejnych czterech starych księgach ${ }^{155}$.

Kolejna z panien sióstr, Joanna Nepomucena Szołdrska ${ }^{156}$, podpisała dzieło Mikołaja Mościckiego Akademia pobożności $i^{157}$, zaznaczając, że otrzymała je od matki w I745 roku, a jedną z ksiąg przejęła z biblioteki trzebnickiej ${ }^{158}$. Następnie Zofia Zaborska ${ }^{159}$ podpisała się w Poczatkach zakonnych dla nowicjuszów... przez jedna zakonna osobę do druku podanych... ${ }^{160}$, a imię Anny Konstancji Gumowskiej ${ }^{161}$ można odnaleźć w trzech innych dziełach ${ }^{162}$. Wzmiankowana wcześniej Ewa Pawłowska pojawiła się także jako właścicielka Parapharasis na psałterz Dawidów Wojciecha Tylkowskiego ${ }^{163}$, a Ludgarda Mieszkowska ${ }^{164}$ pokornie podpisała dzieło Daniela Zielińskiego ${ }^{165}$ jako „,niego[t]da ${ }^{166}$ [tak] stuga boska lutdgarda mieskowska Z T”. Ponadto jedna z mniszek, Eleonora (siostra ksieni Bernardy Paczyńskiej), z racji sprawowanej przez siebie funkcji kantorki, miała za zadanie opiekować się zbiorami bibliotecznymi i je gromadzić, co znalazło odbicie w kilku wpisach własnościowych, umieszczonych na drukach muzycznych ${ }^{167}$.

Co więcej, warto zauważyć, że wśród właścicieli druków obcych, wchodzących w skład księgozbioru trzebnickiego, znalazły się w dużej mierze osoby pochodzenia niemieckiego. Niektóre z ksiąg były własnością mniszek trzebnickich, lecz identyfikacja pozostałych właścicieli jest w znacznym stopniu utrudniona. W gronie właścicielek obcych starodruków znalazły się: Rozalia Weyss ${ }^{168}$, Dorothea Colbertin ${ }^{169}$, Carolina Neussorge ${ }^{170}$, Joahanna

152 Inwentarz, druki, nr 51.

153 Inwentarz, druki, nr 37.

154 Inwentarz, druki, nr 67.

155 Inwentarz, druki, nr 30, 34, 61, 68.

156 Żyła w latach ok. 1730-1799. Zob. M. Borkowska, Skład osobowy..., s. 75.

157 Inwentarz, druki, nr 47.

158 Inwentarz, druki, nr 50.

159 Żyła w latach ok. 1678-1732. Chórowa, od 1728 roku aż do śmierci pełniła funkcję przeoryszy. Zob. M. Borkowska, Skład osobowy..., s. 76.

160 Inwentarz, druki, nr 53.

161 Żyła w latach ok. 1688-1755. Chórowa, w 1744 roku pełniła funkcję podprzeoryszy. Zob. M. Borkowska, Skład osobowy..., s. 69.

${ }^{162}$ Inwentarz, druki, nr 57, 62, 64.

163 Inwentarz, druki, nr 60.

164 Była chórową, zmarła w 1693 roku. Zob. M. Borkowska, Skład osobowy..., s. 72.

${ }^{165}$ Zmarł w 1664 roku. Wstąpił do zakonu bernardynów w 1631 roku w Krakowie. Pełnił m.in. funkcję kaznodziei w Alwerni i Tarnowie, kapelana dworskiego w Chrzanowie czy ponownie w Alwerni gwardiana. Autor kronik prowadzonych w Alwerni i Tarnowie, podręcznika ascetycznego dla nowicjuszy, a także wspomnianych powyżej rozmyślań dla zakonnic. Zob. K. Sitnik, Zieliński Daniel, w: Encyklopedia Katolicka, t. 20, Lublin 2014, kol. 1377; H. E. Wyczawski, Zieliński Daniel, w: SPTK, t. 4, s. 539-540; Inwentarz, druki, nr 69.

166 Tu prawdopodobnie powinno być niegodna.

167 Inwentarz, zbiory muzyczne, nr 2, 3, 5; s. 82.

168 Inwentarz, druki obce, $\mathrm{nr} 2$.

169 Inwentarz, druki obce, nr 3.

170 Inwentarz, druki obce, $\mathrm{nr} 4$. 
Pausewangen $^{171}$, Dorota Malinowska ${ }^{172}$, Humbelina Schimonskin ${ }^{173}$, Ottilia Walchenheim ${ }^{174}$, wspomniana już Scholastyka Hraback ${ }^{175}$, Franciszka von Mułaczewski ${ }^{176}$, Rosina Xöllinin ${ }^{177}$, Peregrine Püsch ${ }^{178}$, Clara Troilo ${ }^{179}$, Dorothea Hillingerin ${ }^{180}$, Marta Henischelin ${ }^{181}$, Magdalena Eisbaldin $^{182}$, Cecylia Mletzko ${ }^{183}$ oraz niejaka Małgorzata Wostrowskin ${ }^{184}$.

Księgi wchodzące w skład biblioteki klasztornej noszą także ślady młodszych zapisów, które bezpośrednio wiążą się z losami księgozbioru na początku XIX wieku. W I8ıo roku, na mocy postanowień króla pruskiego Fryderyka Wilhelma III, przystąpiono do akcji sekularyzacyjnej, wymierzonej w klasztory znajdujące się na terenie Śląska. Zadanie to nadzorowała Główna Komisja Sekularyzacyjna, do której należało odbieranie znoszonym wówczas klasztorom gromadzonych przez wieki księgozbiorów i archiwaliów $w^{185}$. Z ramienia komisji nad realizacją planów czuwał Johann Gustaw Büsching, który, wizytując poszczególne klasztory, dokonywał selekcji wartościowych zbiorów, mając na celu włączenie ich do Biblioteki Centralnej Śląska ${ }^{186}$. Pozostałością po działaniu Büschinga są nalepki proweniencyjne, które umieszczał m.in. na trzebnickich księgach podczas ich katalogowania i przejmowania, co obecnie stanowi dużą wartość i ułatwia ich identyfikację. Ostatecznie najcenniejsze poklasztorne nabytki z cysterskich opactw trafiły w liczbie ponad 360 kodeksów rękopiśmiennych i 63 tysięcy starodruków do powstającej wówczas biblioteki uniwersyteckiej we Wrocławiu ${ }^{187}$. Nie obyło się przy tym bez strat i rozproszenia wielu śląskich księgozbiorów klasztornych, w tym trzebnickiego, który także nie znalazł się tam w całości ${ }^{188}$. Dlatego też wiele ksiąg, wyszczególnionych w inwentarzu Heleny Szwejkowskiej, nosi znaki proweniencyjne wspomnianej biblioteki.

\footnotetext{
${ }^{171}$ Inwentarz, druki obce, nr 5, 19.

${ }^{172}$ Inwentarz, druki obce, nr 6.

173 Inwentarz, druki obce, nr 7, 30.

174 Inwentarz, druki obce, nr 9.

175 Inwentarz, druki obce, nr 23.

176 Mogła to być Franciszka Miłaczewska (albo Mielaczewska), która profesję zakonną złożyła w 1736 roku. Zob. Inwentarz, druki obce, nr 12; M. Borkowska, Skład osobowy..., s. 72.

177 Inwentarz, druki obce, nr 13.

178 Inwentarz, druki obce, nr 15, 24.

179 Inwentarz, druki obce, $\mathrm{nr} 16$.

180 Inwentarz, druki obce, nr 20.

181 Inwentarz, druki obce, nr 21.

182 Inwentarz, druki obce, nr 25.

183 Inwentarz, druki obce, nr 26.

184 Inwentarz, druki obce, nr 28.

185 Inwentarz, s. 8.

186 Tamże, s. 8-9.

187 Biblioteka powstała w 1815 roku pod nazwą Königliche und Universitäts-Bibliothek. Zob. Inwentarz, s. 9; P. P. Gach, Cystersi na ziemiach dawnej Rzeczypospolitej i Śląska w latach 1772-1914, w: Monasticon Cisterciense Poloniae. Dzieje i kultura męskich klasztorów cysterskich na ziemiach polskich i dawnej Rzeczypospolitej od średniowiecza do czasów współczesnych, t. 1, red. A. M. Wyrwa, J. Strzelczyk, K. Kaczmarek, Poznań 1999, s. 85.

188 Inwentarz, s. 10.
} 


\section{Provenience Notes and Books' Owners in the Library of the Cistercian Monastery in Trzebnica in the view of the Inventory of Helena Szwejkowska Summary}

Many of the marks of ownership were included in the inventory of the Library of the Cistercian Monastery in Trzebnica. Owners and history of individual book are known to us thanks to the provenience notes which Helena Szwejkowska recorded in her catalogue. The author of the abovementioned work gathered all provenience notes into a few groups, which allowed us to see how the book collection was growing.

That was possible because of buying books and people who decided to give their books to the monastery library. Although it was forbidden, a lot of nuns were in private possession of books and when they died their books become part of library in Trzebnica. Abbesses of the monastery in Trzebnica were also listed in Szwejkowska's catalogue as book's owners.

By provenience notes we can also see the connections between the monastery in Trzebnica and other Cistercian monasteries in Polish-Lithuanian Commonwealth eg. Lubiąż, Jemielnica, Przemęt. Also there was an exchange of books between Trzebnica and it's branch in Owińska.

Many of the books were brought to Trzebnica by priests who were confessors and sermonizers to Cistercian nuns. There are evidences that some of the books were brought to the monastery in Trzebnica by Eugeniusz Lenga (who later was an abbot in Jemielnica) and Benedykt Cieszkont (who used to be the confessor in Trzebnica). Kasper from Przemęt has to be mentioned as the one who brought some of the manuscripts.

A lot of highly valuable information can be read by historians from margin notes and other marks that were written on the pages of books in the library in Trzebnica. Especially important are provenience marks from the period of the dissolution of the monastery when all the precious books were removed from Trzebnica by Johann Gustaw Büsching.

Keywords: Trzebnica, monastery library, Cistercian nuns, inventory, provenience notes

\section{BIBLIOGRAFIA}

\section{Źródła drukowane}

Legenda świętej Jadwigi, tłum. A. Jochelson, M. W. Gogolewska, Wrocław 1993.

Szwejkowska H., Biblioteka klasztoru cystersek w Trzebnicy, Wrocław I955.

Szwejkowska H., Druki obce, w: Biblioteka klasztoru cystersek w Trzebnicy, Wrocław I955, nr I-3I.

Szwejkowska H., Druki z bibliotek obcych, majace noty rękopiśmienne, dotyczace Trzebnicy, w: Biblioteka klasztoru cystersek w Trzebnicy, Wrocław I955, nr I-3.

Szwejkowska H., Polonica, w: Biblioteka klasztoru cystersek w Trzebnicy, Wrocław I955, nr I-70.

Szwejkowska H., Rękopisy, w: Biblioteka klasztoru cystersek w Trzebnicy, Wrocław I955, nr I-62.

Szwejkowska H., Wydawnictwa poświęcone przez autorów zakonnicom trzebnickim (dedykacje drukowane), w: Biblioteka klasztoru cystersek $w$ Trzebnicy, Wrocław 1955, nr I-6.

Opracowania

Bieś A. P., Wysocki Szymon, w: Encyklopedia Katolicka, t. 20, Lublin 20I4, kol. I082. 
Barciak A., Gorzelik J., Woszczyce-Rudy, w: Monasticon Cisterciense Poloniae. Katalog męskich klasztorów cysterskich na ziemiach polskich i dawnej Rzeczypospolitej, t. 2, red. A. M. Wyrwa, J. Strzelczyk, K. Kaczmarek, Poznań I999, s. 36I-369.

Bochnak W., Niewiasta mężna i czcigodna. Z życia i działalności św. Jadwigi Ślaskiej, w: Bulla kanonizacyjna św. Jadwigi Śląskiej, red. W. Bochnak, Legnica 20I4, s. 7-46.

Borkowska M., Leksykon zakonnic polskich epoki przedrozbiorowej, t. I, Warszawa 2004.

Borkowska M., Skład osobowy polskich klasztorów cysterek w XVII-XVIII wieku, w: Cysterki $w$ dziejach i kulturze ziem polskich, dawnej Rzeczypospolitej i Europy Środkowej, red. A. M. Wyrwa, A. Kiełbasa, J. Swastek, Poznań 2004, s. 62-79.

Doroszewska A., Otoczenie Henryka Brodatego i Jadwigi jako środowisko społeczne, Warszawa 1978.

Gach P. P., Cystersi na ziemiach dawnej Rzeczypospolitej i Ślaska w latach I772-I9I4, w: Monasticon Cisterciense Poloniae. Dzieje i kultura męskich klasztorów cysterskich na ziemiach polskich i dawnej Rzeczypospolitej od średniowiecza do czasów współczesnych, t. I, red. A. M. Wyrwa, J. Strzelczyk, K. Kaczmarek, Poznań I999, s. 74-93.

Gerlic H., Cystersi „,górnoślascy” spowiednikami cysterek trzebnickich, w: Cysterki w dziejach i kulturze ziem polskich, dawnej Rzeczypospolitej i Europy Środkowej, red. A. M. Wyrwa, A. Kiełbasa, J. Swastek, Poznań 2004, s. I30-I54.

Graczyk W., Księgozbiór klasztoru-eremu karmelitów bosych w Czernej od XVII do końca XIX wieku. Studium z dziejów kultury intelektualnej i duchowej, Kraków $201 \mathrm{I}$.

Grzebień L., Brzechwa Stanisław, w: Słownik Polskich Teologów Katolickich (dalej: SPTK), t. I, red. H. E. Wyczawski, Warszawa I98I, s. 234-235.

Grzebień L., Brzechwa Stanisław, w: Encyklopedia Katolicka, t. 2, Lublin 1976, kol. II23.

Grzebień L., Miaskowski Adrian, w: SPTK, t. 3, red. H. E. Wyczawski, Warszawa I982, s. IOO-IOI.

Grzebień L., Wysocki Szymon, w: SPKT, t. 4, red. H. E. Wyczawski, Warszawa I983, s. 486-488. Kaczmarek M., ...Ut et matris et matertere memoriam confoveret. Klasztor trzebnicki pod rzadami opatki Gertrudy (I232-I268), w: Cysterki w dziejach i kulturze ziem polskich, dawnej Rzeczypospolitej i Europy Środkowej, red. A. M. Wyrwa, A. Kiełbasa, J. Swastek, Poznań 2004, s. 328-344.

Kaczmarek R., Witkowski J., Fundacje artystyczne opatki trzebnickiej Krystyny Katarzyny z Wierzbna Pawłowskiej, w: Historia i kultura cystersów w dawnej Polsce i ich europejskie zwiazki, red. J. Strzelczyk, Poznań I987, s. 453-474.

Kaczmarek R., Witkowski J., Kaplica św. Jadwigi w Trzebnicy. Wyposażenie i funkcjonowanie od XIII do XVIII w., w: Cysterki w dziejach i kulturze ziem polskich, dawnej Rzeczypospolitej i Europy Środkowej, red. A. M. Wyrwa, A. Kiełbasa, J. Swastek, Poznań 2004, s. 453-474.

Kanior M., Pierwsze fundacje cysterek na ziemiach polskich, w: Cysterki $w$ dziejach i kulturze ziem polskich, dawnej Rzeczypospolitej i Europy Środkowej, red. A. M. Wyrwa, A. Kiełbasa, J. Swastek, Poznań 2004, s. 39-5I.

Kasjanuk E., Opatowski Adam, w: Encyklopedia Katolicka, t. I4, Lublin 20I0, kol. 6I3-6I4. Kiełbasa A., Mecenat polskich ksień cysterek $w$ Trzebnicy, Trzebnica 2010.

Majkowski J., Alvarez de Paz, w: Encyklopedia Katolicka, t. I, Lublin I973, kol. 396-397. Majkowski J., Arias Franciszek, w: Encyklopedia Katolicka, t. I, Lublin I973, kol. 9I6. 
Nastalska-Wiśnicka J., Rudy Wielkie, w: Encyklopedia Katolicka, t. I7, Lublin 20I2, kol. 558-559.

Ozorowski E., Mikołaj z Mościsk, w: SPTK, t. 3, red. H. E. Wyczawski, Warszawa I982, S. II8-I2O.

Piechnik L., Organizacja bibliotek jezuickich w Polsce od XVI do XVIII wieku, „Archiwa, Biblioteki i Muzea Kościelne”, 30/1975, s. 223-278.

Pohorecki E., Grymosz Marcin Teofil, w: Encyklopedia Katolicka, t. 6, Lublin 1993, kol. 256.

Rajman J., Wolska A., Wolski M., Jemielnica, w: Monasticon Cisterciense Poloniae. Katalog męskich klasztorów cysterskich na ziemiach polskich $i$ dawnej Rzeczypospolitej, t. 2, red. A. M. Wyrwa, J. Strzelczyk, K. Kaczmarek, Poznań I999, s. 79-89.

Sitnik K., Zieliński Daniel, w: Encyklopedia Katolicka, t. 20, Lublin 20I4, kol. I377.

Sobera T., Przemęt, w: Encyklopedia Katolicka, t. I6, Lublin 20I2, kol. 642.

Sutowicz A., Dorobek rękopiśmienny ślaskich klasztorów żeńskich (XIII-XVIII w.), „Wrocławski Przegląd Teologiczny", I6/2008, nr 2, s. I55-I79.

Sutowicz A., Polska ksiązka w ręku cysterek trzebnickich. Przykład XVII-wiecznych modlitewników przechowywanych w Bibliotece Uniwersyteckiej we Wrocławiu, „Świdnickie Studia Teologiczne", Io/20I3, nr IO, s. 353-368.

Swastek J., Rodzina świętej Jadwigi, w: Księga Jadwiżańska. Międzynarodowe Sympozjum Naukowe ,Święta Jadwiga w dziejach i kulturze Śląsk”. Wrocław-Trzebnica 2I-23 września 1993 roku, red. M. Kaczmarek, M. L. Wójcik, Wrocław I995, s. 43-59.

Warzecha M., Księżniczki z domu Piastów górnośląskich w klasztorze trzebnickim, w: Cysterki w dziejach i kulturze ziem polskich, dawnej Rzeczypospolitej i Europy Środkowej, red. A. M. Wyrwa, A. Kiełbasa, J. Swastek, Poznań 2004, s. 489-496.

Wyczawski H. E., Treter Maciej Kazimierz, w: SPTK, t. 4, red. H. E. Wyczawski, Warszawa I983, s. 344-345.

Wyczawski H. E., Zieliński Daniel, w: SPTK, t. 4, red. H. E. Wyczawski, Warszawa I983, S. 539-540.

Wyrwa A. M., Organizacja wewnętrzna w klasztorach cysterek Polskiej Prowincji Cystersów w świetle Statutów Edmunda od Krzyża z 1580 r., w: Cysterki w dziejach i kulturze ziem polskich, dawnej Rzeczypospolitej i Europy Środkowej, red. A. M. Wyrwa, A. Kiełbasa, J. Swastek, Poznań 2004, s. 52-6I.

Ziemann E., Miaskowski Adrian, w: Encyklopedia Katolicka, t. I2, Lublin 2008, kol. 767-768. 